Table 1-Self reported drug use and non-fatal overdose among 1018 drug injectors interviewed in Glasgow, 1993-4

\begin{tabular}{lccc}
$\begin{array}{l}\text { Drug used or injected in } \\
\text { six months before Interview }\end{array}$ & $\begin{array}{c}\text { No (\%) } \\
\text { using } \\
\text { drug }\end{array}$ & $\begin{array}{c}\text { No (\%) } \\
\text { reporting } \\
\text { overdose }\end{array}$ & $\begin{array}{c}\text { Relative risk } \\
\text { (95\% confidence interval) } \\
\text { compared with } \\
\text { rest of sample }\end{array}$ \\
\hline Injected heroin only & $241(24)$ & $52(22)$ & $0.7(0.5$ to 0.9$)$ \\
Injected heroin and other drugs & $661(65)$ & $213(32)$ & $2.2(1.6$ to 3.0$)$ \\
Injected drugs excluding heroin & $116(11)$ & $11(9)$ & $0.3(0.1$ to 0.5$)$ \\
Methadone & $453(44)$ & $132(29)$ & $1.2(0.9 \text { to } 1.6)^{*}$ \\
Buprenorphine & $413(41)$ & $109(26)$ & $0.9(0.7 \text { to } 1.2)^{*}$ \\
Temazepam & $793(78)$ & $244(31)$ & $2.7(1.8$ to 4.0$)$ \\
Cocaine & $179(18)$ & $67(37)$ & $1.8(1.3$ to 2.5$)$ \\
Ecstasy & $258(25)$ & $99(38)$ & $2.0(1.5$ to 2.8)
\end{tabular}

*Not significant.

Preliminary observation suggests that nonfatal overdosing is linearly related to polydrug use; among the 298 subjects who had injected only one drug $57(19 \%)$ had taken an overdose compared with $29(40 \%)$ of the 72 who reported injecting six or more drugs. Among the 116 using multiple drugs excluding heroin, however, only $10 \%$ reported overdosing, compared with $22 \%$ of the 241 who had injected only heroin and $32 \%$ of the 661 who had injected heroin plus other drugs (table 1).

It is important to note that the drugs shown in table 1 do not relate specifically to overdoses; they relate to general patterns of drug use in the six months before interview. Use of temazepam, cocaine, and ecstasy was associated with an increased risk of overdose. In contrast, use of methadone was not associated with overdosing although we are currently conducting a more detailed study of overdosing among drug users who have been prescribed methadone as a part of a city-wide scheme initiated in January 1994.

AVRIL TAYLOR Behavioural scientis MARTIN FRISCHER Behavioural epidemiologis DAVID GOLDBERG Consultant epidemiologist

Scottish Centre for Infection and Environmental Health, Ruchill Hospital,

Glasgow G20 9NB

1 Gossop M, Griffiths P, Powis B, Williamson S, Strang J. Frequency of non-fatal heroin overdose: survey of heroin
users recruited in non-clinical settings. BMF 1996;313:402. (17 August.)

\section{Private practice}

\section{Offering preferential NHS treatment to doctors is embarrassing}

EDTTOR,-I entirely agree with David Currie's personal view about private health insurance: would not allow myself or my family to be treated anywhere other than in NHS hospitals, because for all its difficulties the NHS provides a full range of health care in an accountable manner. But I have had private insurance since I was a senior house officer. Why? Because I am embarrassed by the preferential treatment and queue jumping that my colleagues (and I myself) offer to doctors and their families. By taking myself and my family into the private sector I am not pushing someone else down the list; I am not making staff equally uncomfortable about treating us differently or treating us the same.

What I would not contemplate is treatment in private hospital-without access to full medical records, dedicated nursing staff led by people interested in quality and progress, highly selected junior doctors with structured supervision of their postgraduate education, and a range of consultants to consult if all is not simple and straightforward.
Readers may laugh at that description of an NHS hospital: I would have to agree that it is not quite like that, but it is our aim.

Do I engage in private practice? Yes, occasionally, if people are insured and are also eligible for NHS treatment so that I never have to give a lesser service. And only in the private ward of an NHS hospital. What do I think patients get out of "going private"? Self esteem, their own bathroom, and quiet nights. What do they lose? The context in which to judge the severity of their condition and progress, camaraderie with staff and patients engaged in making the NHS work, and the privilege of training the new generation of professionals.

People should not give up on an organisation that is imperfect: only from the inside- whether it be as a BMA member, an NHS consultant, a recognised BUPA specialist, or a patient - can they influence it.

MARY G BARRINGTON Consultant physician in medicine for the elderly Airedale General Hospital,

1 Currie D. BUPA subscription? That will do nicely. BMf 1996;313:431. (17 August.)

Same standards of stafing and equipment should apply in NHS and private sector

EDITOR,-I endorse everything that David Currie writes in his personal view about private practice. ${ }^{1}$ Some 40 years ago I joined a long established practice in north London. "We try not to send patients in privately," explained one of the partners; "we find too many come out feet first." Nothing that happened over the subsequent years changed my view. In fact, so convinced am I that the best of health care is provided by the NHS that I have waited, sometimes in pain and unable to walk, for the three joint replacement operations I have had over the past three years. Fortunately, any complications I have had have been minor, but during my most recent admission two patients had cerebrovascular accidents one Saturday morning. Other patients and I may have felt a bit neglected, and I do not know the eventual outcome, but I do know that expert care was there immediately, on the spot.

It is not that I have any principled objection to private practice; people should be allowed to spend their money as they like, and if access to a secretary and a good wine list are important they may choose the private sector. But they must do so in the full knowledge of what they are buying. I want that fashionable concept of our age, a level playing field. Incompetent doctors who have been dismissed from the NHS should not be allowed to continue in private practice; the same standards of staffing and equipment should apply in both sectors; and the endless criticisms of the NHS that appear in the press-often, in my experience, baseless - should be matched by similar scrutiny of private hospitals.

It is a matter for shame for the profession that so many doctors have been prepared to treat patients for money in circumstances that they knew were not satisfactory. Perhaps I should add that neither I (a general practitioner) nor my husband (a surgeon) took private patients for exactly the reasons that Currie states.

ANNE SAVAGE Retired general practitioner

Akenside Road,

ondon NW3 5RA

1 Currie D. BUPA subscription? That will do nicely. BMF 1996;313:431. (17 August.)

Author is lucky that his waiting list can be managed quickly

EDITOR,-It is lucky for David Currie that he works in a unit and in an area of Britain where the waiting lists can be managed quickly and personally, making private insurance less attractive. ${ }^{1}$ It is also fortunate that he works in a field in which the need for private care is less than that in other fields and the need for first class back up in the NHS is essential and recognised as such by the NHS administration.

There are many reasons for the size and nature of any surgical specialist waiting list, and "fiddling the system," as Currie suggests, is not the main one. ${ }^{2}$ In my own specialty of plastic surgery most cosmetic, non-malignant, and non-traumatic work is not covered by insurance, and, because of the continual heavy input and referrals, waiting time and waiting lists are difficult to control. Some patients elect to have private treatment and pay for it themselves, mainly for convenience and speed; in some cases they indicate that they are happy to have the freedom of choice and, by removing themselves from the NHS, allow others to take their place in the queue.

JOHN C MCGREGOR

St John's Hospital, Consultant plastic surgeo

Livingston,

West Lothian EH54 6PP

Currie D. BUPA subscription? That will do nicely. $B M 9$ 1996;313:431. (17 August.)

2 McGregor JC. Can a work-load coding system be used to assess and monitor a plastic surgery waiting list? $\mathcal{f} R$ Coll Surg Edinb 1996;41:50-3.

\section{Many reasons exist for choosing private} treatment

EDITOR,-Having read David Currie's personal view about private medicine, I am not sure whether to pity him or be jealous. ${ }^{1}$ His article must surely have been written tongue in cheek. Does he really not know the use of having a subscription for private treatment?

All of us should see a patient urgently if asked to do so. If the next clinic is not soon enough then a special arrangement can be made, such as to admit the patient directly to the ward or to send the patient to the accident and emergency department, whose remit, surely, is emergencies.

Currie is lucky indeed if the pressure of his work allows him to perform all his elective surgery within six weeks; most of us still have waiting lists that are too long. When patients mention that they are insured it is because they assume (quite correctly) that there will be a long wait for routine treatment One must have a warped sense of values if one feels that one is being bribed. By treating such patients privately, out of NHS hours, one is making space to treat other patients more rapidly.

Currie talks of "tin pot nursing homes," but it is surely up to each practitioner to be confiden that he or she practises in a safe environment. 
I would not perform a major operation in a private hospital that was not set up to deal with the complications. Treating private patients in the NHS base brings money into the trust.

I believe that the NHS provides a good service. The reasons for paying a private subscription, however, are many and include being able to see a consultant of your choice (this is more difficult in the NHS since the advent of extracontractual referrals); to have your consultations and be treated promptly and conveniently and in pleasant surroundings (this does not happen in most NHS settings); to enjoy privacy (ditto); and to have a wide choice of edible food (ditto).

If Currie would not allow his family to be treated anywhere other than in his own NHS hospital then the local private hospitals must indeed be in a sorry state, or perhaps he has not visited them recently. It is a shame that Currie has resigned from membership of the BMA at a time when great changes are occurring in his NHS and when the BMA surely needs all the support that it can get.

GEOFF WILSON

Consultant plastic reconstructive and hand surgeon Department of Plastic Surgery,

Queen Mary's University Hospital,

London SW15 5PN

1 Currie D. BUPA subscription? That will do nicely. $B M \mathcal{F}$ 1996;313:431. (17 August.)

Insurers, doctors, and patients do not need to be apologetic about private treatment

EDIToR,- - The private sector facilities that David Currie describes in his area bear no resemblance to those of the clinics in which I work. ${ }^{1}$ The days when private treatment was restricted to minor surgery in "dubious nursing homes" are long past, and the private sector, at least in the south east of Britain, has expanded to cover almost every medical and surgical contingency. In some private clinics facilities are now provided that match and sometimes surpass those in the best NHS units. Of course there are good and bad units-and probably good and bad doctors-in both public and private sectors, and so, unlike Currie, I find it entirely understandable that some people wish to choose for themselves what they consider to be the best available care.

Although most doctors in Britain are committed to the NHS, many can appreciate the advantages of having a private sector in parallel with public facilities. I do not believe that the medical insurers, doctors, or, indeed, patients need be in the least bit apologetic about choosing to operate or be treated outside the NHS. With the advent of audit and accreditation it will not be long before private practice can be conducted only in properly accredited units, and I find it interesting that most hospitals already accredited by the King's Fund are in the independent sector.

Currie's article, in which he refers to his "brooding", "resentment," "enragement," and "spiteful satisfaction," amply testifies to his bigoted perspective; fortunately, both readers and the general public have the freedom to choose whether to be influenced by him. Most, when inquiring about the benefits of private health care, will seek accurate and unbiased information before committing themselves to an opinion, a decision, or, indeed, a subscription.

P J GRAVETT

Department of Haematology,

Consultant haematologist

London Clinic,

London W1N 2DH

1 Currie D. BUPA subscription? That will do nicely. $B M F$

1996;313:431. (17 August.)

${ }_{\star}^{\star \star}$ Of the nine other letters that we received on this subject, three supported private practice while the remaining six agreed with David Currie's views.-EDITOR

\section{Jury is still out on National Blood Service}

EdToR,-E Angela E Robinson criticises Ann Oakley's editorial about blood donation for being based on a catalogue of false premises. ${ }^{12}$ The rosy picture of the English blood transfusion service that Robinson paints, however, does not match my experience. Staff morale, an indicator of the wellbeing of any organisation, is at an all time low as the proposals to rationalise the service are forced through. The departure of so many skilled and experienced staff is also a matter of considerable concern to users of the service.

Though Robinson rightly thanks donors for their ever increasing number of donations, she claims that the volume of blood collected is determined by hospitals' needs. While this may be broadly true, too many serious shortages of blood have occurred. For example, during 1995 stocks of $\mathrm{O}$ negative red cell units fell below the National Blood Authority's own minimum target on $31 \%$ of occasions. Conversely, stocks of group AB red cell units have averaged $11 \%$ of the total national blood stock, although only $3-4 \%$ of patients can receive AB blood. These deficiencies are not indicative of a well managed organisation.

While an increasing number of countries use tests for antibodies to hepatitis B core antigen and to human $\mathrm{T}$ leukaemia/lymphoma virus types I and II, the English blood transfusion service believes that the introduction of these tests is not yet justified. Yet Robinson claims that the National Blood Service is recognised as the finest and safest in the world. On the very day that Robinson's letter was published the popular press reported the withdrawal of batches of factor VIII and human albumin solution because of possible contamination of source plasma with hepatitis C virus; this underlines her own false premise.

An unprecedented number of donors complained that surplus products had been sold without their expressed informed consent. Robinson should therefore heed Oakley's advice about the need for donors to have a greater voice in the use of their blood. This is especially relevant given the changing nature of the blood service, which is no longer supervised by loca clinical directors but is increasingly managed by remote businessmen.

While the old National Blood Transfusion Service may have been among the finest and the safest in the world, the jury is still out regarding the new service controlled by the National Blood Authority.

P J BOWELL

Formerly laboratory services manager, Oxford Blood Centre

35 Deanfield Road,
Oxford OX2 9DW

1 Robinson EAE. Blood donation. BMf 1996;313:428. (17 August.)

2 Oakley A. Blood donation-altruism or profit? $B M f$ 1996;312:1114. (4 May.)

\section{Caring for older people}

\section{Caring for carers should be included in} undergraduate curriculum

EDITOR,-In her article on carers who care for older people Anne F Travers states that carers need recognition, information, and support from the health professionals with whom they are in contact. ${ }^{1}$ A recent Gallup survey, however, showed that $45 \%$ of carers receive no help whatsoever in their caring role. ${ }^{2}$ Since there are an estimated six million carers in Britain, this represents an enormous number of carers not receiving recognition, information, and support. Travers's article offers suggestions that could be implemented in both primary and secondary care to improve support for carers, but I believe that medicine should be proactive at a much earlier stage, with specific teaching on carers, their needs, and sources of support being provided at undergraduate level.

The General Medical Council has recently highlighted the importance posed by chronic illness and disability in an increasingly elderly and disabled population and the fact that all clinicians, regardless of their specialty, should have insight and experience of such care. Despite the council's latest recommendation that teaching on chronic illness and rehabilitation should be included in the core undergraduate medical curriculum, ${ }^{2}$ the amount and content of such teaching in British medical schools is generally inadequate. ${ }^{34}$ The new undergraduate curriculum at Newcastle upon Tyne includes a four week rotation, "chronic illness and rehabilitation," which is mandatory. A session on caring for carers focuses on identifying carers and their needs and providing information and support. I would be interested to know how many (or, I suspect, how few) other medical schools provide such formal teaching.

In patients' and carers' opinions, doctors, especially general practitioners, still have a pivotal role in providing patients with advice and information, ${ }^{5}$ but does current undergraduate and postgraduate medical education adequately equip our doctors with the skills to support carers? The introduction of the Carers (Recognition and Services) Act 1995 will make assessment of carers by local authorities mandatory. Teaching medical students and junior doctors to identify, listen to, and take care of carers should follow a similar course.

L ROBINSON Lecturer in primary health care

Department of Primary Health Care,

School of Health Sciences,

Medical School,

University of Newcastle,

Newcastle upon Tyne NE2 4HH

Travers AF. Caring for older people: carers. $B M f$ 1996;313:482-6. (24 August.)

2 General Medical Council. Tomorrow's doctors. Recommendations on undergraduate medical education. London: GMC, 1993.

3 Marshall J, Haines A. Survey of the teaching of disability and rehabilitation to medical undergraduates: the UK. Med Educ 1990;24:528-30.

4 Kattan S, Inman C, Haines A, Holland P. Teaching disability and rehabilitation to medical students. Med Educ and rehabilitation

5 Chesson RA, Sutherland A. General practice and the provision of information and services for physically disabled people aged 16 to 65 years. Br $\mathcal{F}$ Gen Pract 1992;42:473-6.

\section{Carers need financial assistance to buy help}

EDITOR,-Having personal experience of being a long term carer and having seen some of my friends struggle to fulfil this role, I have become convinced that, while the endeavours of organisations for carers ${ }^{1}$ are to be respected, the only important thing that makes a difference is practical financial help.

The most effective way of ensuring that long term caring does not become a depressing and never ending burden and chore is to find other people to do it for you. However hard people try to tell you that it is a labour of love, sooner or later-if you are having to do everything for the person for whom you care-resentment and anger begin to take over. No amount of recognition, information, and moral support can substitute for a professionally trained person doing the daily work involved in looking after an incapacitated person. Professional carers can go home at the end of the day. Amateur carers are stuck with their duties day and night for seven days a week.

Putting this burden on families is a cheap and nasty way of solving a difficult problem. Support groups, counselling, or a sympathetic ear do not ease the trauma of constantly changing the bed of a doubly incontinent parent, of having to feed 